\title{
MODERN MINING RESCUE CONSIDERING ORGANIZATIONAL AND TECHNICAL CONDITIONS CHANGING IN HARD COAL MINES IN POLAND. STATUS AND PROSPECTS
}

\author{
Piotr HETMAŃCZYK \\ Central Mining Institute, Katowice; phetmanczyk @ gig.eu, ORCID: 0000-0001-8816-6037
}

Purpose: the main purpose of the article is to underline importance of updating knowledge by mine rescuers related to deteriorating geological conditions of mines, that can lead to accidents and events that result in serious disasters.

Design/methodology/approach: theses presented in the article have been verified using: literature review, critical literature analysis, document research and comparative analysis.

Findings: based on content of this article, mining rescue will be considered as the most important aspect of the entire occupational safety system. The main element in mine rescue is the lifeguard-specialist, who has unique and constantly improving qualifications and professional competences. Hence, the role and quality of mining rescue should be assessed not only in the scope of the tasks that it has to perform, but also perhaps even more importantly, in relation to new challenges that require the constant adaptation of mining rescue to fit dynamically changing organizational and technical conditions, both underground and on the surface of the mine.

Originality/value: the article enriches knowledge and develops discussion in the area of mining rescue. Thanks to the knowledge presented in the article, it can be concluded that role and the rank of mining rescue lies not only in the dimension of tasks that it has to perform, but also importantly in the dimension of new challenges that determine the need to constantly adapt mining rescue to dynamically changing organizational and technical conditions, both underground and on the surface of mine sites.

Keywords: mine industry, mine rescue, safety.

Category of the paper: Conceptual paper.

\section{Introduction}

Hard coal mining is a special industry due to specific problems associated with particular determinants in the area of occupational safety. Geological conditions, the occurrence of natural hazards and working conditions unique to the mining industry, are the source of many accidents and events that can lead to serious disasters. In light of this, the operation of mining rescue 
services is a priority due to the need to ensure the safety of mining crews. On the basis of the above thesis, it should be recognized that mine rescue is integrally connected with the factors of the natural working environment, which also include the negative effects of natural hazards (Gadowska, 2011, pp. 20-30). Polish underground mining has undergone many years of restructuring, initiated in the last decade of the twentieth century. The key determinants of this restructuring are: a significantly decreasing number of mines, a dynamic drop in mining and employment, and ownership changes (Ocena stanu bezpieczeństwa pracy..., 2019, pp. 8-26). As a result of restructuring activities in the second decade of the 21 st century, Polish mining has become profitable and has adapted in order to function in a competitive market economy.

In this context, it is worth noting that hard coal mining in Poland, being the largest producer of coal in the European Union, is characterized by extremely complicated geological and mining conditions characterized by the occurrence of all manner of natural hazards known to hard coal mining. The general division of threats occurring in mining includes natural, technical and organizational-human hazards. Constantly increasing the concentration of extraction and depth of exploitation has an adverse effect and can lead to an increase in natural hazards (Tkocz, and Heder, 2012, pp. 243-260). At the end of 2018, under the supervision of the State Mining Authority, there were 20 mines employing 76974 people with production at 63384 thousand tonnes (Kabiesz, 2019, pp. 6-7).

In the area of indicated potential, mining rescue is the most important link in the entire work safety system. The main element is the lifeguard-specialist, with unique and constantly improving qualifications. Taking into account the fact that coal exploitation is carried out at ever greater depths, which leads to increased hazards in the work environment, mining rescue faces new and previously unknown challenges. This results in the need for the systematic modernization of mine rescue service, which is determined by the following factors:

- motivation to work in rescue services, which is defined as a complex set of factors resulting from the recruitment process, health status of the candidate and professional prestige,

- costs and benefits resulting from the extension of professional credentials,

- financial outlays incurred to optimize the security of mining rescue operations at the highest possible organizational and technical level.

\section{Legal basis of mining rescue functioning}

Mining rescue is within the field of general security, meaning operational activity at all levels of state security management, in all states of its functioning, in circumstances or in relation to the circumstances surrounding the response to threats in an immediate (immediate and urgent) manner, aimed at counteracting individual, institutional and general issues related to the 
functioning of the enterprise providing mining services. Thus, the perception of mining rescue is limited only to operations of an operational nature, which are not at odds with the possibility of public service providers providing mining rescue services of a restrictive, preventive and even logistic nature.

The organization and functioning of mining rescue services in Poland are included in the Notice of the Speaker of the Sejm of the Republic of Poland of April 4, 2019, regarding the publication of a uniform text of the Act - Geological and Mining Law (Journal of Laws from 2019, item 868) and in the order issued on the basis of art. 124 of this Act, the Ordinance of the Minister of Energy of 16 March 2017 on mining rescue (Journal of Laws of 2016, item 1131). The latter specifies, among others: organization, tasks, and equipment for mine rescue services and entities professionally engaged in mining rescue.

According to statutory provisions, mining rescue is connected with immediate assistance in three cases: threat to life or health of persons in a mining plant, occurrence of a mine plant safety threat and a threat to public safety. It also includes the proper eradication of threats (Obwieszczenie..., 2019).

It is worth noting that the legislator in the enacted law includes the possibility of threats to individual security (towards persons at risk in a direct way), institutional security (in relation to a company providing mining services), and even general security (in relation to the whole society, and consequently to national security) (Lebecki, 2015, pp. 29-30). In addition, legal recognition of mine rescue goes beyond its operational perception (in reference to preventive actions).

\section{Mining rescue organization}

In Poland, the mining rescue system is based on the activity of specialized rescue stations and rescue services of mining entrepreneurs. At the end of 2018, 31 mining rescue stations and 3 mining rescue points were maintained. The total number of rescuers in hard coal mines was 4105 people (including supervisors - who represent 21\% of this figure) (Mikilis, 2017, pp. 2-3).

Currently, three entities (mine rescue units) are professionally engaged in mine rescue operate in Poland's mining industry:

- The Central Mining Rescue Station S.A. in Bytom, which by the end of 2018 covered three district mining rescue stations. CSRG S.A. was established as a commercial law entity, providing a full service to mining plants of hard coal and other mineral resources;

- Division/Rescue Unit of Mining and Metallurgy of KGHM Polska Miedź S.A. in Lubin. This is the rescue service of KGHM Polska Miedź SA; it protects copper mines, brown coal mines and mineral mines; 
- Well Mining Rescue Station in Cracow. This was created as a rescue service for PGNiG Polish Oil and Gas Company SA, and it performs services for enterprises active in seeking and extracting crude oil and natural gas.

According to the law, each mining rescue unit must meet the requirements necessary for performing mining rescue operations, including the use of rescue teams and specialized ambulances kept in constant readiness, along with the equipment necessary to carry out the tasks.

A rescue unit's tasks, in addition to providing immediate help to mine sites, include:

- organizing and conducting courses in the field of mine rescue,

- conducting exercises in the field of mining rescue,

- conducting medical examinations of mine rescuers at a specialized medical examination center,

- examination and evaluation of rescue equipment,

- performing specialized analyzes of chemical air samples (Rozporządzenie..., 2017).

In terms of equipment, each rescue unit should hold (§ 27.1) (Rozporządzenie ..., 2017):

- respiratory protection equipment,

- measuring and control instruments,

- rescue and auxiliary equipment,

- medical equipment,

- personal protection equipment and protective clothing.

\section{Socio-economic conditions of modern mining rescue}

As previously noted in the introduction of this article, environmental challenges are a significant problem for modern mining, which together with the protection of mineral resources constitute a pillar of sustainable development. On the scale of global mining, they cover a wide range of problems and concern all aspects of the natural environment, i.e. the surface of the earth, water and air (Drebenstedt, 2008, pp. 135-147; Dubiński, and Turek, 2006, pp. 4-9). Virtually every piece of mining activity violates to a lesser or greater extent the state of the natural environment. Therefore, it is necessary to develop technologies for obtaining mineral resources that will eliminate or minimize the negative effects of mining processes. It is also necessary to develop technology that will mitigate and remediate the existing effects so that the areas degraded by mining can be restored for further use.

In turn, social responsibility in the mining of mineral resources focuses primarily on the issues of occupational health and safety, and thus on the care for the health and life of the worker at his/her place of work (Dubiński, 2011). The concept of occupational health and safety in mining consists of a wide range of interrelated technical, social, organizational and legal 
elements. Their level and the degree of implementation in the form of so-called good practices have a decisive impact on work safety. When analyzing the problem of work safety in mining on a global scale, it should be stated that the industry of obtaining mineral resources, especially in underground mining conditions, belongs to sectors of the economy with a high level of risk of accidents - some of which have disastrous consequences. This level of risk varies both for individual countries that are at different levels of technological development and for different types of mining.

Of the factors that may encourage individuals to work in rescue services, the most frequently mentioned by rescuers is the possibility to help and their willingness to work in difficult situations. It is worth noting that economic return factors (remuneration and conversion rate of seniority) were slightly lower than the national average (Hetmańczyk, and Tausz, 2009). Other factors that encourage individuals to work in this area are family labor traditions in mining and professional satisfaction (Hetmańczyk, and Tausz, 2009).

An important component of the rescuers' work is obligatory medical examinations, theoretical training and exercise. Health and training requirements are more restrictive for mine rescuers - they are subjected to specialist medical and psychological tests, as well as preventive periodic examinations with regards to their ability to work underground; in addition, each year they should take part in six training exercises (Miklis, 2017, pp. 2-3).

It must be stressed that a mine rescuer performs professional activities in conditions of increased risk, not only during rescue operations, but also often during preventive work. Therefore, his/her service requires both appropriate equipment for the type of rescue operation associated with the occurrence of specific hazards and an appropriate training and training exercises system. Internationally, Polish mining rescuers are perceived as having a very high level of skills and extensive knowledge in the field of mining rescue. This supports their repeated participation in international rescue missions and training (Ocena stanu bezpieczeństwa pracy..., 2019, pp. 8-26).

\section{Summary}

Mining rescue occupies a special place in the mining plant safety system. The reason for this is that mine rescue exists to counter and even prevent crisis situations that lead to threats to health and life that result from human error, natural causes and the very nature of mining activity. Mastering a crisis situation is not possible without the participation of "rapid reaction teams", such as rescue teams. Hence the role and the rank of mining rescue lies not only in the dimension of tasks that it has to perform, but also importantly in the dimension of new challenges that determine the need to constantly adapt mining rescue to dynamically changing organizational and technical conditions, both underground and on the surface of mine sites. 


\section{References}

1. Drebenstedt, C. (2008). Responsible mining - approaches and realization. Proc. 22nd World Mining Congress - Innovations and Challenges in Mining, 1. Istanbul, 135-147.

2. Dubiński, J. (2011). Safe and environmental friendly coal mining - global challenge for the XXI century. Beijing.

3. Dubiński, J., Turek, M. (2006). Proces restrukturyzacji a ochrona środowiska na terenach górniczych. Bezp. Prac. i Ochr. Środ. w Górn. 12, 4-9.

4. Gadowska, K. (2011). Ratownictwo górnicze w kopalniach węgla kamiennego. Uwarunkowania techniczne, ekonomiczne, organizacyjne i społeczne. Katowice: GIG.

5. Hetmańćzyk, P., Tausz, K. (2009). Stużba ratownicza w opinii ratowników górniczych. Praca statutowa GIG, Katowice.

6. Kabiesz, J. (2019). Raport roczny o stanie podstawowych zagrożeń naturalnych i technicznych w górnictwie węgla kamiennego. Katowice: GIG.

7. Lebecki, K. (2015). Bezpieczeństwo pracy w górnictwie światowym. Rat. Gór., 1(78), 29-30.

8. Miklis, P. (2017). Funkcjonowanie ratownictwa $w$ górnictwie węgla kamiennego. Warszawa: NIK.

9. Obwieszczenie z dnia 4 kwietnia 2019 r. Prawo geologiczne i górnicze, Dz.U. z 2019 r. poz. 868 (2019).

10. Ocena stanu bezpieczeństwa pracy, ratownictwa górniczego oraz bezpieczeństwa powszechnego w zwiąku z działalnościa górniczo-geologiczna w 2018 roku (2019). Katowice: WUG.

11. Rozporządzenie Ministra Energii z dnia 16 marca 2017 r. w sprawie ratownictwa górniczego (Dz.U. z 2016 r. poz. 1131).

12. Tkocz, M., Heder, A. (2012). Działalność innowacyjna upadającej branży przemysłowej na przykładzie górnictwa węgla kamiennego. Prace Kom. Geogr. Przem. Pol. Tow. Geogr., 20, 243-260. 